\title{
IDENTIFYING THE NARRATOR OF HADITH IN THE CRITICISM OF SANAD
}

\author{
Jannah Lukman \\ Program Studi Ilmu Al-Quran dan Tafsir Fakultas Dakwah dan Ushuluddin, IAIN Takengon. \\ Jl. Yos Sudarso No. 2, Blangkolak 1, Takengon, Aceh Tengah \\ Email: jan22nah@gmail.com \\ DOI: http:dx.doi.org/10.32505/al-bukhari.v3i2.1910 \\ Submitted: 2020/09/02 | Revised: 2020/10/16 | Accepted: 2020/11/02
}

\begin{abstract}
The Prophetic Hadith has been criticized by sanad and isnad analyzing.In this study, the author explained the narrators of Hadith identity needed based on 'Ilmu rijāl al-Hadīs. This study aimed to identify the narrators of Hadith correctly and identify their biography objectively to prevent and avoid misidentify in sanad. This process of analyses aims to win sanad quality. This research is a qualitatve study using analytical description to explain the resources. The primary data used in this study is a book the so-called 'Ulüm al-Hadīś. The research found out many aspects are pivotal for considerations in identifyng the rawi when someone wants to quote his hadith, such as ensuring the name, nasab, nisbah, kuniah, maula, mutasyäbih, mubham, laqab, teacher and student, rihlah, tarikh, and thabaqat. This research alsofound the book of the narrator's biography resourches to help the process of identifications.
\end{abstract}

Keyword: 'Ilm Rijal al-Hadiś, Identifying Narrator of Hadith, Criticism of Sanad

\begin{abstract}
Abstrak
Hadis-hadis dikritisi dengan melakukan telaah sanad hadis dan isnad-nya. Pada kajian ini penulis akan menjelaskan beberapa identitas perawi yang perlu diteliti dalam bidang ilmu rijāl al-Hadïs. Kajian ini bertujuan agar identitas perawi dapat diteliti secara benar dan bagaimana telaah yang lengkap terhadap pribadi perawi sehingga pengkritik sanad dapat membedakan antara satu perawi dengan perawi lainnya. Hal ini penting agar dapat diketahui kualitas sanad sebuah hadis. Metode yang digunakan dalam kajian adalah metode analisis deskriptif. Data yang dikumpulkan menggunakan metode kualitatif dimana data primer diambil dari kitab-kitab 'ulūm al-Hadīs yang muktabar. Pada akhirnya, kajian ini menemukan ada beberapa pengetahuan yang perlu disingkap ketika mengidentifikasi perawi yaitu pada saat peneliti merujuk kepada kitab biografi perawi yaitu dengan memastikan nama dan nasab perawi, nisbah, kunyah, maula, perkara mutasyabih, mubham, gelar, syuyūkh dan murid, rihlah, tarīkh, tabaqat perawi. Kajian ini juga menemukan kitab-kitab rujukan yang muktabar dalam identifikasi perawi yang dicari.
\end{abstract}

Kata Kunci: Ilmu Rijal al-Hadiś, Identifikasi Perawi, Kritik Sanad 


\section{Introduction}

Islam obliges us to obey the commands of the Qoran and the commands contained in the prophet's tradition (known as Hadith). Therefore, Hadith is the second source of law in Islam after the Qoran. ${ }^{1}$ The discussion about Hadith and its problems is a matter concerned by the Hadith scholars.

Hadith scholars have compiled the sciences related to the Hadith of the Prophet PBUH. One of them is The Science of the Narrator of Hadith, known as 'ilm rijal alHadiś. Rijal al-Hadiś means Rawi or narrator of Hadith. The word of rawi (also means narrator) comes from the word riwayah (means narration). Riwayah literally means writing (defined as an-naql), giving a drink until satisfied (defined as al-istisqa') and chanting (defined as al-zikr). In terms of Hadith science, riwayah means the activity of receiving and conveying Hadith and relying on the Hadith to a series of narrators in a certain forms. ${ }^{2}$ So, rawi or rijal al-Hadiś or narrator of Hadith means the person who has done the activity of riwayat.

To carry out the narration of the Hadith, there are three elements that must be fulfilled, namely:

\section{1. receiving the Hadith;}

\footnotetext{
${ }^{1}$ Sayyid 'Abd al-Majid Al-Ghāwi, Al-Sunnah AlNabawiyyah Hujjiyyatuhā Wa Tadwinuhā Dirāsah 'Ammah (Beirut: Dār Ibn Kaśir, 2009), 19.

${ }^{2}$ M. Sayuthi Ali, "Periwayatan Hadis Dengan Lafaz Dan Makna," Alqalam Vol. 11, no. 59 (1996): 20.
}

2. delivering the Hadith to other;

3. when presenting a hadith, the narrator or rawi must mention the series of narrators.

Thus, a person cannot be said to be a narrator of Hadith if he does not convey the Hadith to others; or he passed the Hadith to someone else but he did not mention the series of Hadith narrators. ${ }^{3}$

The science of the narrator of Hadith is a science that explores the narrators of the Hadith mentioned in chain of narrator (known as sanad). This aims to examine the identity of the narrators so that it can be seen whether the narrator meets other narrators to form a strong chain of narrators or whether there is a cut off (known as inqita' or tadlis) in the sanad. This knowledge is also known as the Science of Narrators Dates ( 'ilm tarikh ar-ruwat) or the History of narrators.

The aim of criticizing the Hadith, either its sanad or matan, is to identify the authenticity of a Hadith. The eventual outcome of this criticism is to ascertain if the Hadith fulfils the condition on authenticity and enables the differentiation of an acceptable (known as maqbul) or rejected (known as mardud) Hadith. ${ }^{4}$

\footnotetext{
${ }^{3}$ Ali, Periwayatan, 22.

${ }^{4}$ Tuan Mohd Sapuan Tuan Ismail et al., "The Matan and Sanad Criticisms in Evaluating the Hadith," Asian Social Science Vol. 10, no. 21 (2014): $152-158$.
} 
In Arabic, the synonym for criticism is the word naqd, which means to separate something from something other than it. ${ }^{5}$

Some Hadith scholars prefer to use the term criticism associated with al-jarh wa al-ta 'dil. Al-jarh wa al-ta'dil is a science that shows the cancellation and justice of a Hadith. Thus Hadith criticism is associated with Hadith narrators leaning on the Prophet Muhammad which is in accordance with the rules or conditions of the valid Hadith requirements. The purpose of criticizing this Hadith is to find the authenticity of the Hadith so that the Hadith can be trusted and has a valid degree as the Hadith of the Prophet. ${ }^{6}$

The scope of criticism of Hadith is the sanad and matn of the Hadith. However, this study focuses on the study of the identification of narrators to assist in criticism of sanad. In examining narrators, we must understand the importance of each narrator data we collect. What are the important data related to narrators in the criticism of sanad and how is the explanation further? In this study, the steps in conducting

\footnotetext{
${ }^{5}$ For example: naqada al-kalam wa naqada alsyi ' $r$ means separating the words from the verse; or naqada al-darāhim means separating good money and bad money. Mustafa Azami, M, Metodologi Kritik Hadits, (Malang: Pustaka Hidayah, 1992), 81

6 Thofiqur Rohman and Ulul Huda, "Methodology of Hadith Research: The Study of Hadith Criticism Metode Penelitian Hadis: Studi Tentang Kritik Hadis,' Journal of Hadith Studies Vol. 2, no. 1 (2019): 73-84.
}

the criticism of sanad are explained, namely what things is needed to recognize the narrator so that the criticism of sanad can be carried out appropriately.

In addition, the books on the science of narrators of Hadith have been written by Hadith scholars and make it easier for us to carry out criticism of sanad study to prove the authenticity of a Hadith. Then, what are the identities of the narrators that we need to explore when conducting criticism of sanad in order to find a biography of the narrator that is correct and not mistaken? What kind of books can we use when identifying narrators? This research aimed to identify the narrators of Hadith correctly by accumulating their biography objectively to prevent and avoid misidentify in sanad. This process of analyze is to win sanad quality.

This research is qualitative research. The data for this research were collected from the books of Hadith sciences (known as 'ulum al-Hadiś) as well as the books of criticism of sanad. In compiling the data, this study uses an applicable theoretical literature method with examples to make it easy to understand. This study uses descriptive analysis method in explaining result. The author examines what aspects need to be studied in identifying narrators or looking for the identity of the narrators of the Hadith so that the person (known as ain) and the true 
narrator's personality (known as hal al-rawi) are discovered. This is important so that the narrator of Hadith could be identified correctly. Furthermore, to explain the study of the identities of Hadith narrators in applicative form, the author describes the classic famous books (known as turaś) for searching the narrator's identity according to the aspects of the narrator's biographical study that have been described previously.

\section{Study of Identification of Narrators and It's Characteristics}

The study of the authenticity of the Hadith usually begins with a study of its sanad. As M. M. Azami thought that the authenticity of the sanad of Hadith has a high enough accuracy to determine authenticity. Therefore, conducting an investigation into sanad is very important beside there has been 'slander' (known as fitna) among Muslims in the past so that many fabricated Hadiths (known as al-Hadiś al-maudu ) have arisen. ${ }^{7}$

After conducting a critical study of sanad and when the quality of the sanad has been determined, the assessment of Hadits is the same (linear) as the assessment of the sanad. $^{8}$

7 Umayyah Syarifah, "Kontribusi Muhammad Musthafa Azami Dalam Pemikiran Hadis (Counter Atas Kritik Orentalis)," ULUL ALBAB Jurnal Studi Islam Vol. 15, no. 2 (2015): 222.

${ }^{8}$ Andi Rahman, "Pengenalan Atas Takhrij Hadis," Riwayah: Jurnal Studi Hadis Vol. 2, no. 1 (2017): 146.
The study of sanad and the actual narrative (known as matn) actually existed at the beginning of the Islamic date. Some experts claim that studies in the actual narrative criticism of the Hadith came before chain of narrator criticism its own. According to them, the study of the actual narrative was carried out at the time of the Prophet PBUH, while the study of chain of narrator was only implemented after the killing of The Caliph 'Othman bin 'Affan in $35 \mathrm{H}$. At that time, the chain of narrator criticism that was carried out by accentuation the side of the narrator's morality; or was only applied after the death of The Caliph 'Othman, as stated by Ibn Sirin (d. $110 \mathrm{H})$, that initially people did not ask the news bearer (narrator). However, after the "slander" occurred, people started asking questions about the individual moral integrity of the person who brought the news about the Hadith. The deep concern among the Hadith scholars with the efforts to fabricate Hadith then pushed them to standardize the authenticity of Hadith which then continued to the process of Hadith extraction and authentication (known as takhrij). ${ }^{9}$

Criticism of sanad is activity of doing a research on the truth of sanad. It can be identified by means of two elements, namely

\footnotetext{
${ }^{9}$ Ibid.
} 
the quality of the narrative and the connection of the sanad. The steps used to determine the quality of the narrator and the connection of the sanad are as follows:

1. collect all the sanad of Hadith and do the sanad study (i ‘tibar al-sanad);

2. examine the narrators and how the narrations are used. In this step, all the data about narrator information about biographies, jarh wa al-ta'dil in the books of tabaqat and siyar and other books. Then do examining the quality of the narrative in terms of justice and thoroughness. If after analysis it turns out that the narrator is siqah, then the narration is accepted;

3. examine the data that has been obtained in order to find out whether a narrator with the student and teacher has met, contemporaries and whether it has a teacher-student relationship so that it can be seen whether the series of rawi is continuous or not;

4. make conclusions about the degree of the Hadith. ${ }^{10}$

As for examining a sanad and identifying a narrator of Hadith, there are several things that must be emphasized and ascertained by the sanad reviewers. This is not an easy duty because sometimes narrators

${ }^{10}$ Rizkiyatul Imtyas, "Metode Kritik Sanad Dan Matan," Ushuluna: Jurnal Ilmu Ushuluddin Vol. 1, no. 1 (2020): 18-32. have the same name as other narrators; or their names are the same but their classes (known as tabaqat) is different; or their teknonyms (known as kunya) is the same. Therefore, to criticize the information about narrators properly and avoid wrong identification, the following are things that need to be examined by sanad researchers, they are:

1. Knowing the epithet (known as laqab) of narrators or muhaddiś and the reasons for mentioning this epithet. ${ }^{11}$

This is important so that researchers do not mistakenly find narrators or even misinterprete the narrators. As for the epithet given to distinguish one narrator from another narrator, it is not meant to mock or do useless. Examples:

a) Mu'awiyah bin 'Abd al-Karim ad-Dall. His epithet ad-Dall (meaning: the straggler) was given because he was once lost on the road in Mecca.

b) 'Abdullah bin Muhammad ad-Da'if. His epithet ad-Da if (meaning: a weak person) was given because he once had weaknesses in his body, not weak in his Hadith. $^{12}$

2. Know the land of birth and country of the narrators

\footnotetext{
${ }^{11} \mathrm{Abu}$ 'Amru 'Uśmān bin 'Abd al-Rahmān Ibnu Salāh, 'Ulum Al-Hadiś (Halab: Matba'ah al'Ilmiyyah, 1931), 330.

${ }^{12}$ Salāh, 'Ulum, 330.
} 
By knowing the place where the narrator was born and the country where the narrator was raised, the sanad researcher could know the toponym (known as nisba) and who the teachers are (known as syuyukh) because it may be that the narrator's name is similar to the names of other narrators, but they can be distinguished by knowing the toponym of the land of birth of each narrator. In fact, sometimes the native Arabs were ordained to a tribe, the leaders, the poets or to a house. But the people of 'Ajam (not native Arabs) are ordained to their nation, their ancestors or their country. For example, the Children of Israel were ordained to their ancestors Isra'il (epithet of The Prophet Ya'qub PUBH). Meanwhile, the Muslims who spread to several areas were ordained to cities or villages. Al-Hafiz Ibnu Kaśir said, "Some of them say: The patronym (known as nasab) is only ordained to the country when the narrator has lived for four years or more."13

3. Knowing the date or history of the narrator's life.

Knowing the narrator's dates is one of the branches of the Hadith science by which it is known whether the sanad is connected to the Prophet Muhammad PBUH or is cut off. As for the history of this narrator's life, it could be seen from the person who met the

\footnotetext{
${ }^{13}$ Ibnu Kaśir, Al-Ba 'iś Al-Haśiś Syarh Ikhtisar 'Ulum Al-Hadiś (Riyad: Maktabah al-Ma'arif, 1996).
}

narrator, that is, the person who never found the narrator committing lies or tadlis. The sanad researcher can also find out the journey of narrators for seeking the knowledge (known as rihlah ilmiyyah), that was the places he has visited.

The Hadith of the Prophet was not only based in Medina but spread to various parts of the Islamic country at that time. Rihlah 'ilmiyyah is done by Hadith narrators to obtain Hadiths that are not yet known or have not been memorized. Rihlah 'ilmiyyah is also carried out to verify the Hadiths they have memorized and even hunt down the main source of Hadith in order to minimize the series of sanads, namely looking for the shortest sanad ('uluw isnad). ${ }^{14}$

The sanad researchers can also find out from whom the narrators took the Hadith (syuyukh or their teachers) and to whom the Hadith was taught (talamiż or their students). The researchers can also find out the praise or criticism of the Hadith scholars against the narrators. In addition, the researcher must be able to find the year of birth and death of the narrator. Sufyan al-Śuri said, "When he used narrators who lied we used history." Hafas bin Giyaś said, "If you accuse a teacher (known as shaykh) then reckon with the year

14 Amrulloh, "Fenomena Rihlah Ilmiah Demi Hadis Pada Masa Periwayatannya (1-4H/7-10M)," Religi: Jurnal Studi Islam Vol. 6, no. 1 (2015): 19-45. 
of his life." That was, his age and the age of the people who wrote about him. ${ }^{15}$

4. Knowing the trustworthy (known as siqah) or weakness (known as da'if) of the narrator's. ${ }^{16}$

The trustworthy of narrators (known as śiqah) or weakness of narrators (known as $d a$ 'if) by mastering isnad criticism (known as 'ilm al-jarh wa at-ta'dil). By mastering the words of criticizing (known as jarh) and the words of praising (known as ta'dil), the sanad researcher can determine whether the narrator can be accepted or rejected by the Hadith. Then what if there are those who gave jarh and there are those who gave ta 'dil to this narrator? This requires further research to find which one is more appropriate. In examining the characters of the narrators of hadith, it is mandatory to refer to several 'theories of al-jarh wa atta'dil', so that the results of the research can be objective. ${ }^{17}$

5. Know the narrator's name and their teknonym (known as kunya).

That is, the researcher must know the teknonym of narrator and look for his real

${ }^{15} \mathrm{Abu}$ 'Abdullah Muhammad bin 'Abdullah alHakim an-Naisaburi, Ma'rifat 'Ulum al-Hadiś, (alMadinah al-Munawwarah: Dar al-Kutub al-'Ilmiyyah, 1977), 208

${ }^{16}$ Kaśir, $A l-B a$ 'iś, 664

17 Heru Widodo, Fahmi Irfanudin, and Corresponding Author, "AL JARH WA AT-TA' DIL IN RESEARCHING SANAD," Journal of Hadith Studies Vol. 3, no. 1 (2020): 23-33. name. There are several Hadith scholars who compiled books about names and kunya of narrators, among them are Ali bin al-Madini, Muslim, Al-Nasa'i, al-Hakim and Ibnu 'Abd al-Barr.

Knowing this matter is necessary because sometimes a narrator has a name such as kunya and then it is as if there is another kunya. For example: Abu Bakr bin 'Abd al-Rahman al-Hariś. His name is Abu Bakr and his kunya is Abu 'Abd al-Rahman. Then, Abu Bakr is not his kunya.

There are the narrators known by their kunya and their name are not known, for example: Abu Muwaihibah, Abu Syaibah alKhudri and others.

Meanwhile, there is the narrator given the epithet (known as laqab) with kunya instead of being famous for his kunya, for example: 'Ali bin Abi Talib was given the title Abu Turab even though his kunya was Abu al-Hasan.

There is narrator who has two kunya, for example 'Umar bin al-Khattab. His kunya was Abu al-Qasim, then he replaced it with Abu 'Abd al-Rahman because Abu al-Qasim is the kunya of The Prophet PBUH.

Sometimes the narrator has a famous kunya but he has a disputed real name, for example; Abu Hurairah. His name was disputed both before and after converting to Islam. However, the most corroborated 
opinion about his name is 'Abd al-Rahman bin Sakhr al-Dusi. ${ }^{18}$

6. Knowing the classes of narrator (known as tabaqat) and Hadith scholars (known as muhaddiś).

Knowing this section is necessery because there might be narrators who were contemporary with other narrators or they were in the same age and had a similar isnad. Maybe they had the same teacher. This certainly could help us to find the continuity of the sanad. ${ }^{19}$

7. Knowing the people whose their memorization was back and forth at the end of their lives.

Sometimes there is a narrator who is known as trustworthy (known as siqah), but at the end of his life, something is wrong with his memory because it could be that his memory starts to weaken, became blind, or became sick. For example: 'Ata' bin alSa'ib, Abu Ishaq al-Sabi'i, Husain bin 'Abd al-Rahman, 'Abd al-Razzaq bin Hammam. We can accept transmitted science (known as marwiyat) from them when their memory is strong and reject their transmitted science when their precision has dwindled. ${ }^{20}$
8. Knowing the narrator who is mentioned by various names and various characteristics. ${ }^{21}$

It is very important to know whether there is tadlis in the sanad. For example: Muhammad bin al-Sa'ib al-Kalabi is considered a weak narrator. His name was disputed. Some say his name is Hammad bin al-Sa'ib. There are also those who say his kunya is Abu al-Nadr and there are those who say his kunya is Abu Sa'id. ${ }^{22}$

9. Knowing indefinite narrator (known as mubham).

Indefinite narrators or people who are not named in the isnad can be traced by looking for the relationship between the person and the narrator before and after or we can find out through other sanad channels. In addition, we could pay attention to to the words of the indefinite name (known as ibham) whether the single word (known as mufrad) is like a man, a woman, men, women; or there are the relation (known as idafah) such as a man's sons, a man's daughters, uncle, aunts, grandparents, a woman's husband or a man's wife. By knowing the identity of the indefinite narrator, we can know the trustworthy of narrator or his weakness. ${ }^{23}$

\footnotetext{
${ }^{21}$ Salāh, 'Ulum, 312; Kaśir, Al-Ba 'iś, 573-574

${ }^{22}$ Salāh, 'Ulum, 312; Kaśir, Al-Ba 'iś,573-574

${ }^{23}$ Salāh, 'Ulum, 376-381
} 
10. Knowing the teknonym of narrator known by his name without the teknonym hisself.

This session is important because sometimes a narrator is known by his name rather than by his teknonym. In some narrators they have different names but have the same teknonym. For examples: there are many narrators whose teknonym is Abu Muhammad such as al-Asy'aś bin Qais, Śabit bin Qais, Jabir bin Mut'im, al-Hasan bin 'Ali, Huwaitib bin 'Abd al-'Uzza, and Talhah bin 'Ubaidillah. Likewise there are many narrators whoseteknonym is $\mathrm{Abu}$ 'Abdullah, such as az-Zubair bin 'Awwam, Husain bin 'Ali bin Abi Talib, Salman alFarisi and Hużaifah bin al-Yaman. There were also many narrators whose teknonym is Abu 'Abd al-Rahman, such as 'Abdullah bin Mas'ud, Mu'aż bin Jabal, Zaid bin alKhattab, 'Abdullah bin 'Umar bin alKhattab and Mu'awiyah bin Abi Sufyan. ${ }^{24}$

11. Knowing that the narrator is not being ordained to his father.

Sometimes narrators are ordained to their mother, grandmother, grandfather or step father, for examples:

a. Mu'aż bin 'Afra'. 'Afra' is the name of Mu'aż's mother;

${ }^{24}$ Salāh, 'Ulum, 327-329 b. Ya'la bin Maniyyah. Maniyyah is the name of Ya'la's grandmother. Maniyyah is his father's mother. Meanwhile, Ya'la's father was named Umayyah;

c. Abu 'Ubaidah bin al-Jarrah. His teknonym is $\mathrm{Abu}$ 'Ubaidah. His name is'Amir bin 'Abdullah bin al-Jarrah alFihri. Al-Jarrah is the name of $\mathrm{Abu}$ 'Ubaidah's grandfather.

d. Al-Miqdad bin al-Aswad. His real name is 'Amru bin Tsa'labah al-Kindi al-Bahrani. Al-Aswad is the name of al-Miqdad's step father. Al-Aswad married al-Miqdad's mother, namely Rabibah. They both raised al-Miqdad. Then, al-Miqdad is ordained to alAswad. $^{25}$

\section{Knowing the maula of narrators}

Several narrators are attributed to their maula. Maula could be defined as the guardian or the free slave. Maula can also mean an ally of the tribe because there is an oath of loyalty. This is important to know so that researchers do not misidentify the narrator and think that the narrator comes from the lineage of his maula. ${ }^{26}$

13. Knowing toponym of the narrator (known as nisba) text which contradicts what is mentioned.

\footnotetext{
${ }^{25}$ Salāh, 'Ulum, 373-374

${ }^{26}$ Salāh, 'Ulum, 414-415
} 
Sometimes a narrator is attributed to a different place or tribe from that of his father's. For example: Abu Mas'ud 'Uqbah bin 'Amru al-Badari. Al-Bukhari thought alBadari is the toponym because he joined the Battle of Badr. Otherwise, according to majority of the scholars, the toponym of alBadari was because he lived close to the location of the Battle of Badr. ${ }^{27}$ Another example is Ahmad bin Yusuf al-Salami. It seems that he is attributed The Tribe of Salam, known as the name of his mother's tribe. But, if we examine, his father came from Bani Asad. So in fact, his toponym should be Ahmad bin Yusuf al-Asadi. ${ }^{28}$

14. Knowing the narrators who are mutasyabih.

Al-mutasyabih are narrators who have similarities in their names or the names of their parents in writing but differ in their spelling. This could happen due to the similarity of the hijaiyyah letter which is distinguished by the dot and without a line (shakal). There are two kinds of almutasyabih, they are:

a. The narrators whose the same name, but the names of his parents are mutasyabih. For example Musa bin 'Ali with Musa

\footnotetext{
${ }^{27}$ Salāh, 'Ulum, 646.

${ }^{28}$ Salāh, 'Ulum, 648.
}

bin 'Ulayy. ${ }^{29}$ 'Ali and 'Ulayy are the same in Arabic script but different in spelling. Another example is Muhammad bin 'Aqil with Muhammad bin 'Uqail. 'Aqil and 'Uqail are the same in Arabic script but different in spelling.

b. The narrators whose name is mutasyabih but the names of the parents are the same. For example Shuraih bin al$\mathrm{Nu}$ 'man with Suraij bin al-Nu'man. The $h a^{\prime}$ in Shuraih and the jim in Suraij are the same because they are written without dots in the manuscript. Another example is Muhammad bin 'Abdullah al-Mukharrimi with Muhammad bin 'Abdullah al-Makhrami. The writings of al-Mukharrimi and al-Makhrami are the same because the letters have no lines (shakal) in the manuscript, but the spelling is different. ${ }^{30}$

\section{Knowing al-Musytabih al-Maqlub}

al-Musytabih al-Maqlub is a narrator whose name and patronym (known as nasab) are similar but different in birth. This results in a mistaken perception for researchers if

29 'Abd al-Rahman bin Abi Bakar, Tadrib alRāwi fi Syarh Taqrib al-Nawāwi, (al-Mamlakah al'Arabiyyah al-Su'udiyyah: Dār Ibn al-Jauzi, 1431H), 954-956.

${ }^{30}$ Ahmad bin 'Ali bin Hajar al-'Asqalani, Nuzhat al-Nazr Syarh Nukhbat al-Fikr min al-Akhbār, (t.t.p: Maktabat Manārāt al-'Ulamā' li Ihyā' al-Turaś alIslami, 1989), 63. 
there is a similarity in the name of the narrator or his father, then the name is reversed. For examples:

a. Muslim bin al-Walid with al-Walid bin Muslim.

b. Yazid bin al-Aswad with al-Aswad bin Yazid. $^{31}$

\section{Narrator Identification Chart}

For researchers there are many things that must be known about the narrator. In the simple terms, a description of the identification of the narrators can be seen in the following chart:

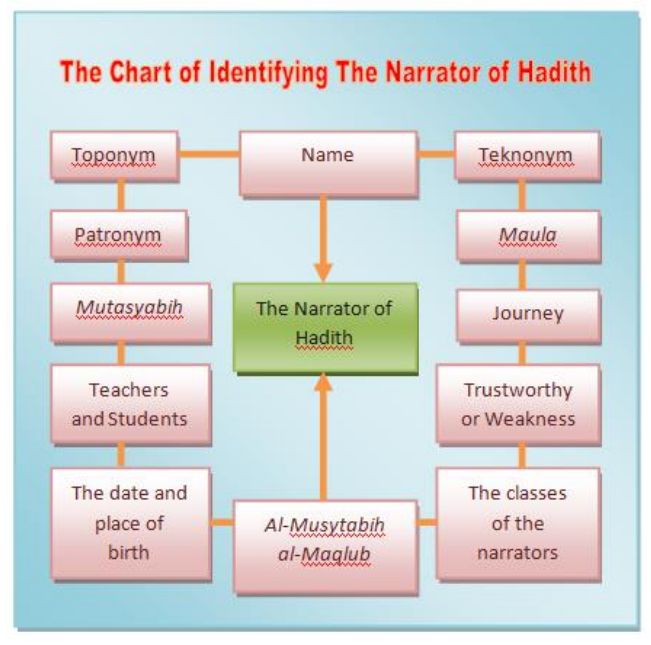

Chart 1. Identifying The Narrator of Hadith

\section{Biographical Books of The Narrators (known as Kutub Rijal al-Hadiś)}

${ }^{31}$ Salāh, 'Ulum, 372
Many biographical books of narrators (rijal al-Hadiś) have been compiled by Hadith scholars. $^{32}$ This is inseparable from the development of Hadith Science (known as 'ulum al-Hadiś or Mustalah al-Hadiś) and 'ilm rijal al-Hadis. ${ }^{33}$ Study of Mustalah Hadith is a study that concern with basic terms on the study of hadith research. ${ }^{34}$ The sanad researchers can study the biographies of the narrators by reference to these books. The sanad researchers can study the biographies of the narrators by reference to these books. To make it easier for researchers, this study summarizes several books that can be used to research rijal alHadiś or Hadith narrators, including:

1. Al-Isabah fi Tamyiz al-Sahabah. It is compiled by Ahmad bin Muhammad bin Hajar al-'Asqalani, better known as Ibn Hajar al-'Asqalani. The book is a reference for the biographies of the

${ }^{32}$ The reference books that have been compiled by Hadith scholars relating to the science of rijal alHadiś can be classified into: 1) The books compiled for certain books;2) The books compiled about thethiqah narrators; 3) The books compiled about the da'if narrator commented on; 4) The books compiled about the tabaqat(levels of narrator); 5) Books that are compiled about narrators based on certain countries; 6) The books are compiled about narrators in general; 7) The books compiled about the biographies of companions of The Prophet. Dr. Kauśar Mahmud al-Salami, Mabāhiś fi al-Takhrij Dirāsat alAsānid al-Jarh wa al-Ta'dil, (Kairo: Jāmi'at al-Azhar, 2009), 102

${ }^{33}$ Mr. Suryadi, "Rekonstruksi Kritik Sanad Dan Matan Dalam Studi Hadis," ESENSIA: Jurnal IlmuIlmu Ushuluddin Vol. 16, no. 2 (2015): 177.

${ }^{34}$ Rohman, Methodology, 73-84 
companions of the Prophet sallallahu 'alaihi wa sallam which contains their biographies and their kunya.

2. Usd al-Gabah fi Ma'rifat al-Sahabah. It is written by 'Izz al-Din bin Muhammad bin al-Aśir al-Jazari, better known as Ibnu al-Aśir. The book is also a biographical book of the companions of The Prophet.

3. Tahżib at-Tahżib. It is compiled by Ibn Hajar al-'Asqalani. It is a book containing biographies of the narrators of the Hadith Kutubal-Sittah or the six main Hadith books, namely Sahih al-Bukhari, Sahih Muslim, Sunan Abi Daud, Sunan al-Tirmizi, Sunan al-Nasa'I and Sunan Ibnu Majah.

4. Taqrib at-Tahżib. It is also written by Ibn Hajar al-'Asqalani. This book is a summary of The Book Tahżib at-Tahżib.

5. Ikmal Tahżib al-Kamal, written by Yusuf bin al-Żaki al-Mizzi, which also contains the narrator's biography Kutub alSittah. $^{35}$

6. Al-Tabaqat al-Kubra, written by Muhammad bin Sa'ad bin Mani‘ Abu 'Abdillah al-Basri al-Hasyimi. The book isbetter known as Tabaqat Ibn Sa'ad. This book is a book about the levels of Hadith narrators (known as tabaqat) which are the biggest and best.

\footnotetext{
${ }^{35}$ Suryadi, Rekonstruksi, 177-178
}

7. Al-Śiqat, written by Muhammad bin Hibban bin Ahmad bin Hibban, better known as Ibn Hibban. The book contains the biographies of narrators who are siqah only or those that are said by Imam Ibn Hibban as śiqah.

8. Al-Tarikh al-Kabir, at-Tarikh al-Ausat, at-Tarikh al-Sagir and Kitab Al-Du 'afa' which are written by Imam al-Bukhari. They are the biographical books of Hadith narrators that he narrated.

9. Kitab Tarikh written by Yahya bin Ma'in which is a biographical book of narrators as well.

10. Al-Majruhin min al-Muhaddiśin compiled by Ibn Hibban contains the biography of the narrator who has been condemned as disabled or weak in riwayah.

11. Al-Kamil fi Du 'afa' al-Rijal compiled by Abu Ahmad 'Abdullah bin 'Adi alJurjani, who is better known as Ibn 'Adi. This book is a biography of the da'if narrators along with an explanation of the causes of their jarh and also a biography of the narrators of majhul or the unknown narrator.

12. Al-Mubhamat written by Abu al-Qasim bin Basykual. This book contains biographies of the narrators who are mubham and are well-known books. 
13. Al-Mustafad min Mubhamat al-Matn wa al-Isnad written by al-'Iraqi. This book is a biographical book of mubham narrators and is also a refinement of the three books about the mubham written by al-Khatib al-Bagdadi, Ibn Basykual and an-Nawawi.

14. Jami ‘ al-Usul written by Ibn al-Aśir which also contains a mubham narrator. ${ }^{36}$

15. Talkhis al-Mutasyabih fi al-Rasmi wa Himayah Ma Asykala minhu 'an Bawadir al-Tashif wa al-Wahmi written by al-Khatib al-Bagdadi. This book is about narrators whose mutasyabih or names are similar to one another This book was summarized by 'Uśman bin Mustafā bin Sulayman who was known as Ibn al-Turkimani. ${ }^{37}$

16. Tuhfat al-Nabih bi Talkhis alMutasyabih written by Jalal al-Din alSuyuti. This book is also a summary of our Talkhis al-Mutasyabih above.

17. Rafi 'al-Irtibab fi al-Maqlub min alAsma' wa al-Ansab written by al-Khatib al-Bagdadi. This book is a book of descriptions of narrators whose names are

${ }^{36}$ DR.Ratibah Ibrahim Khattab Tahun, Al-Wajiz fi 'Ilm Mustalah al-Hadiś, (Kairo: Jāmi'at al-Azhar, 2004), 60.

${ }^{37}$ Tahun, Al-Wajiz, 64. similar and may be reversed in the narration. $^{38}$

\section{Conclusion}

The discussion about the criticism of sanad Hadith of Rasulullah sallallahu 'alaihi wa sallam is something that has been the concern of scholars for a long time. The scholars of Hadith have compiled the sciences related to Hadith, one of which is the science of rijāl al-Hadiś, which examines matters relating to the narrators of Hadith contained in the sanad (the chain of narrator) so that the identity of the narrators when criticizing sanad is known. Identification of the narrators of the Hadith is very important in order to know whether the sanad of Hadith under study is continuous or vice versa and there is no misidentify.

For examining a sanad and identify narrators, there are several narrator identities that must be studied by the sanad researchers, they are: the epithet of narrator and the reasons for giving the epithet; land of birth and country of narrator; date or life history of the narrator; the trustworthy (śiqah) or the weakness (da'if) of narrator; the narrator's name and his teknonym (kunya); the classes of narrators (tabaqāt) and Hadith scholars (muhaddiśun); to know

\footnotetext{
${ }^{38}$ Tahun, Al-Wajiz, 64
} 
people whose memorization is back and forth at the end of their lives; to know narrators whose names are many and whose characteristics are various; know the mubham narrator; know the teknonym of the narrator (kunya) known by his name without the teknonym; know the narrator whose the patronym is not attributed to his father; to know maula of the narrator; to know toponym of the narrator (known as nisba) text which contradicts what is mentioned; to know the narrator who is mutasyābih; to know the narrator who is al-musytabih almaqlub.

The books that become references in identifying narrators are books related to matters related to the identity of the narrator as mentioned above, namely special books in the field of 'ilm rijāl al-Hadiś that have been compiled by Hadith scholars. Among these books are: Al-Isābah fi Tamyiz al-Sahābah, Usd al-Gābah fi Ma 'rifat al-Sahābah, Tahżib at-Tahżib, Taqrib al-Tahżib, Ikmāl Tahżib alKamāl, Al-Tabaqāt al-Kubrā, Al-Śiqāt, AlTārikh al-Kabir, Kitab Al-Du'afā', Kitab Tarikh, Al-Majruhin min al-Muhaddiśin, AlKamil fi Du'afa' al-Rijal, Al-Mubhamāt, AlMustafād min Mubhamāt al-Matn wa alIsnād, Jāmi ' al-Usul, Talkhis al-Mutasyābih, Tuhfat al-Nābih, and Rāfi al-Irtibāb fi alMaqlub min al-Asmā' wa al-Ansāb. 


\section{References}

Al-'Asqalani, Ahmad bin 'Ali bin Hajar. Nuzhat al-Nazr Syarh Nukhbat al-Fikr min al-Akhbār. t.t.p: Maktabat Manārāt al-'Ulamā’ li Ihyā’ al-Turaś al-Islami, 1989.

Al-Ghawi, Sayyid 'Abd al-Majid. Al-Sunnah Al-Nabawiyyah Hujjiyyatuha Wa Tadwinuha Dirasah 'Ammah. Beirut: Dar Ibn Kaśir, 2009.

Ali, M. Sayuthi. "Periwayatan Hadis Dengan Lafaz Dan Makna.” Alqalam Vol. 11, no. 59 (1996): 20.

Al-Salami, Dr. Kauśar Mahmud al-Salami. Mabāhiś fi al-Takhrij Dirāsat al-Asānid al-Jarh wa alTa 'dil. Kairo: Jāmi'at al-Azhar, 2009.

Amrulloh. "Fenomena Rihlah Ilmiah Demi Hadis Pada Masa Periwayatannya (1-4H/7-10M)." Religi: Jurnal Studi Islam Vol. 6, no. 1 (2015): 19-45.

An-Naisaburi, Abu 'Abdullah Muhammad bin 'Abdullah al-Hakim. Ma'rifat 'Ulum al-Hadiś. AlMadinah al-Munawwarah: Dar al-Kutub al-'Ilmiyyah, 1977.

Azami, M.Mustafa. Metodologi Kritik Hadits. Malang: Pustaka Hidayah, 1992.

Bakr, 'Abd al-Rahman bin Abi. Tadrib al-Rāwi fi Syarh Taqrib al-Nawāwi. Al-Mamlakah al'Arabiyyah al-Su'udiyyah: Dār Ibn al-Jauzi, 1431H.

Imtyas, Rizkiyatul. "Metode Kritik Sanad Dan Matan.” Ushuluna: Jurnal Ilmu Ushuluddin Vol. 1, no. 1 (2020): 18-32.

Ismail, Tuan Mohd Sapuan Tuan, Rohaizan Baru, Ahmad Fauzi Hassan, Ahmad Zahid Bin Salleh, and Mohd Fauzi Mohd Amin. "The Matan and Sanad Criticisms in Evaluating the Hadith." Asian Social Science Vol. 10, no. 21 (2014): 152-158.

Kaśir, Ibnu. Al-Ba 'iś Al-Haśiś Syarh Ikhtisar 'Ulum Al-Hadiś. Riyad: Maktabah al-Ma'arif, 1996.

Rahman, Andi. "Pengenalan Atas Takhrij Hadis." Riwayah: Jurnal Studi Hadis Vol. 2, no. 1 (2017): 146.

Rohman, Thofiqur, and Ulul Huda. "Methodology of Hadith Research: The Study of Hadith Criticism Metode Penelitian Hadis : Studi Tentang Kritik Hadis." Journal of Hadith Studies Vol. 2, no. 1 (2019): 73-84.

Salah, Abu 'Amru 'Uśman bin 'Abd al-Rahman Ibnu. 'Ulum Al-Hadiś. Aleppo: Matba'ah al'Ilmiyyah, 1931.

Suryadi, Mr. "Rekonstruksi Kritik Sanad Dan Matan Dalam Studi Hadis." ESENSIA: Jurnal IlmuIlmu Ushuluddin Vol. 16, no. 2 (2015): 177.

Syarifah, Umayyah. "Kontribusi Muhammad Musthafa Azami Dalam Pemikiran Hadis (Counter 
Atas Kritik Orentalis).” ULUL ALBAB Jurnal Studi Islam Vol. 15, no. 2 (2015): 222.

Widodo, Heru, Fahmi Irfanudin, and Corresponding Author. “Al Jarh Wa At-Ta' Dil In Researching Sanad." Journal of Hadith Studies Vol. 3, no. 1 (2020): 23-33.

Tahun, DR.Ratibah Ibrahim Khattab. Al-Wajiz fi 'Ilm Mustalah al-Hadiś. Kairo: Jāmi'at al-Azhar, 2004. 